\title{
Concentration of Copper and Lead in Market Milk and Milk Products of Bangladesh
}

\author{
S. M. S. Shahriar ${ }^{1, \star}$, S. Akther ${ }^{2}$, F. Akter ${ }^{3}$, S. Morshed ${ }^{1}$, M. K. Alam², \\ I. Saha ${ }^{3}$, M. A. Halim ${ }^{4}$, M. M. Hassan ${ }^{5}$ \\ ${ }^{1}$ Dept. of Applied Chemistry and Chemical Technology, Chittagong Veterinary and Animal Sciences \\ University, Khulshi, Chittagong - 4225, Bangladesh \\ ${ }^{2}$ Dept. of Food Processing and Engineering, Chittagong Veterinary and Animal Sciences University, \\ Khulshi, Chittagong - 4225, Bangladesh \\ ${ }^{3}$ Dept. of Physical \& Mathmatical Science, Chittagong Veterinary and Animal Sciences University, \\ Khulshi, Chittagong - 4225, Bangladesh \\ ${ }^{4}$ Dept. of Agricultural Economics and Social Science, Chittagong Veterinary and Animal Sciences \\ University, Khulshi, Chittagong - 4225, Bangladesh \\ ${ }^{5}$ Dept. of Physiology, Biochemistry \& Pharmacology, Chittagong Veterinary and Animal Sciences \\ University, Khulshi, Chittagong - 4225, Bangladesh \\ *E-mail address: shahan.acrubd@gmail.com
}

\begin{abstract}
The aim of this work is to detect and estimate the level of selected heavy metals (copper and lead) in milk and milk products in Chittagong City Corporation Areas of Bangladesh. The most important milk and milk products that are likely to be an important contributor to heavy metal exposure was selected. Total 30 samples of milk and milk products were analyzed among these 20 raw milk samples was collected from 20 dairy farms around industrial area in Chittagong City and 10 milk product samples were collected from market in Chittagong City. Detection and estimation of the level of copper and lead were carried out by using "Analytikjena Atomic Absorption Spectrophotometer, model: ZEEnit700P, Germany". It was found that, most of all milk samples contain copper and lead copper and lead. The content of copper in most of all raw milk and milk products were in the range from $0.02 \mathrm{mg} / \mathrm{kg}$ to $0.25 \mathrm{mg} / \mathrm{kg}$. The highest level of copper was found $0.244 \mathrm{mg} / \mathrm{kg}$ in milk products. The concentration of lead in milk and milk products were in the range from $0.007 \mathrm{mg} / \mathrm{kg}$ to $0.02 \mathrm{mg} / \mathrm{kg}$. The highest concentration of lead was found $0.019 \mathrm{mg} / \mathrm{kg}$ in raw milk. These values were compared with standard allowable limit and also with the corresponding values of different countries available in literature.
\end{abstract}

Keywords: Heavy metal; copper; lead; milk; milk products

\section{INTRODUCTION}

Heavy metals are an important source of food contamination and health hazard. The main threats to human health are associated with exposure to arsenic, cadmium, lead, copper 
and mercury. Sources of food contamination include environmental and industrial pollution, agricultural practices, food processing and packaging.

Absorption of heavy metals through food has been shown to have serious consequences on health and thereby economic development associated with a decline in labour productivity as well as the direct costs of treating illnesses such as kidney disease, damage to the nervous system, diminished intellectual capacity, heart disease, gastrointestinal diseases, bone fracture, cancer and death ${ }^{1}$.

Preliminary studies in different parts of Bangladesh indicate that the food chain in is exposed to contamination by heavy metals and trace elements. Islam et $\mathrm{al}^{2}$.found that industrial sludge, often used as a soil conditioner or fertilizer, has high concentrations of heavy metals. Similarly, high levels of heavy metals were found in soils in the Sundarbans ${ }^{3}$. When these metals are absorbed by crops and animals they enter the food chain and constitute a serious health hazard. An analysis of heavy metal concentrations in vegetables in Jessore shows that all of the vegetables commonly consumed in diets contain dangerously high concentrations of heavy metals ${ }^{4}$.

The need to take action to prevent and control contamination of the food chain by heavy metals and trace elements in Bangladesh is therefore becoming increasingly obvious. The National Food Policy Plan of Action (2008-2015) (area of intervention 3.6), as well as other national policies such as the National Agricultural Policy (1999), the National Fisheries Policy (1998), National Livestock Policy (2007), National Plan of Action for Nutrition (1997), the National Health Policy (2010) and the forthcoming National Food Safety Policy and Plan of Action, recognize the importance of reducing food contamination in Bangladesh in order to improve human health.

However, while the extent and sources of arsenic contamination are well known, more comprehensive information on the extent to which the population of Bangladesh is exposed to food contamination by other toxic heavy metals namely Arsenic, Cadmium, Lead, copper and Mercury is not widely available. This undermines the ability for decision makers to recognize the importance of interventions for reducing heavy metal contamination of food. Similarly some minerals and trace elements are insufficiently explored in foods in Bangladesh and newer data would be useful.

This research was done to investigate the exposure of copper and lead in the average diet in Bangladesh, as well levels of contaminations in selected milk and milk products. This will provide information on the dietary exposure to heavy metal contaminants, on its potential health implications as well as the potential sources of contamination and recommendations for action.

\section{EXPERIMENTAL}

\section{1. Sample collection}

Raw milk (M) samples were collected from 25 dairy farms which are situated around Industrial area or waste disposal area in Chittagong city of Bangladesh. Yoghurt (MY) and ghee (MG) (clarified butter) were collected from local market in Chittagong city of Bangladesh.

\section{2. Sample preparation}

Liquid samples were prepared by Acid Digestion method which is described in the literature $^{6}$. In general, nitric acid is used as oxidant alone or in combination with other acids (e.g., sulfuric and hydrochloric acids) or sometimes with hydrogen peroxide ${ }^{7-9}$. In addition, 
hydrofluoric acid can be used in combination with nitric acid for the total decomposition of silica containing organic matrices ${ }^{10}$.

Nitric acid is popular because of its chemical compatibility, oxidizing ability, availability, purity, and low cost ${ }^{11}$. Solid samples were prepared Dry ashing method which is described in literature ${ }^{6}$. Dry ashing or oxidation is usually performed by placing the sample in an open vessel and destroying the combustible (organic) portion of the sample by thermal decomposition, normally in the presence of an ashing aid, using a muffle furnace. Typical ashing temperatures are 450 to $550^{\circ} \mathrm{C}$ at atmospheric pressure, and the ash residues are dissolved in $5-10 \%$ nitric acid.

\section{3. Analytical Methods and Instrumentation}

Copper and lead in milk and milk products were determined according to previously described methods ${ }^{12-13}$. The samples were analyzed in a laboratory with a quality assurance schemes by using "Analytikjena Atomic Absorption Spectrophotometer, model: ZEEnit700P, Germany".

\section{4. Data analysis}

The concentration of copper and lead in milk and milk products were determined by using ASpect LS 1.2.0.0, Analytik Jena AG 2011-2012 system software. Statistical analysis was performed by using SPSS statistical software of version 14. All values were expressed as mean \pm standard error of mean (SEM).

\section{RESULT AND DISCUSSIONS}

Calibration curves for each heavy metal were set to ensure the accuracy of the Atomic Absorption Spectrophotometer and to establish that results of the determination proper were true and reliable. Standards with the concentration of $0.40 \mathrm{ppm}, 0.80 \mathrm{ppm}$, and $1.20 \mathrm{ppm}$ respectively, were set for the calibration of the Atomic Absorption Spectrophotometer. The calibration curve of well prepared standards and an accurate AAS should present as a linear curve. The data on the calibration for copper and lead are seen in Figures 1 and 2 respectively.

Copper and lead contents were determined in 40 samples of milk and milk products collected from Chittagong City Corporation areas of Bangladesh. The results of raw milk sample are given in table 1. It was found that, copper concentrations were significantly high in raw milk.

Among all raw milk the highest copper content was obtained $0.198 \mathrm{mg} / \mathrm{kg}$. The content of copper in most of all raw milk samples were in the range from $0.02 \mathrm{mg} / \mathrm{kg}$ to 0.2 $\mathrm{mg} / \mathrm{kg}$ in the raw milk. Lead concentrations in raw milk were found within maximum allowed limit for lead in raw milk.

The highest concentration of lead in raw milk sample was found $0.019 \mathrm{mg} / \mathrm{kg}$. The concentration of lead in most of all raw milk samples were in the range from $0.008 \mathrm{mg} / \mathrm{kg}$ to $0.020 \mathrm{mg} / \mathrm{kg}$. 


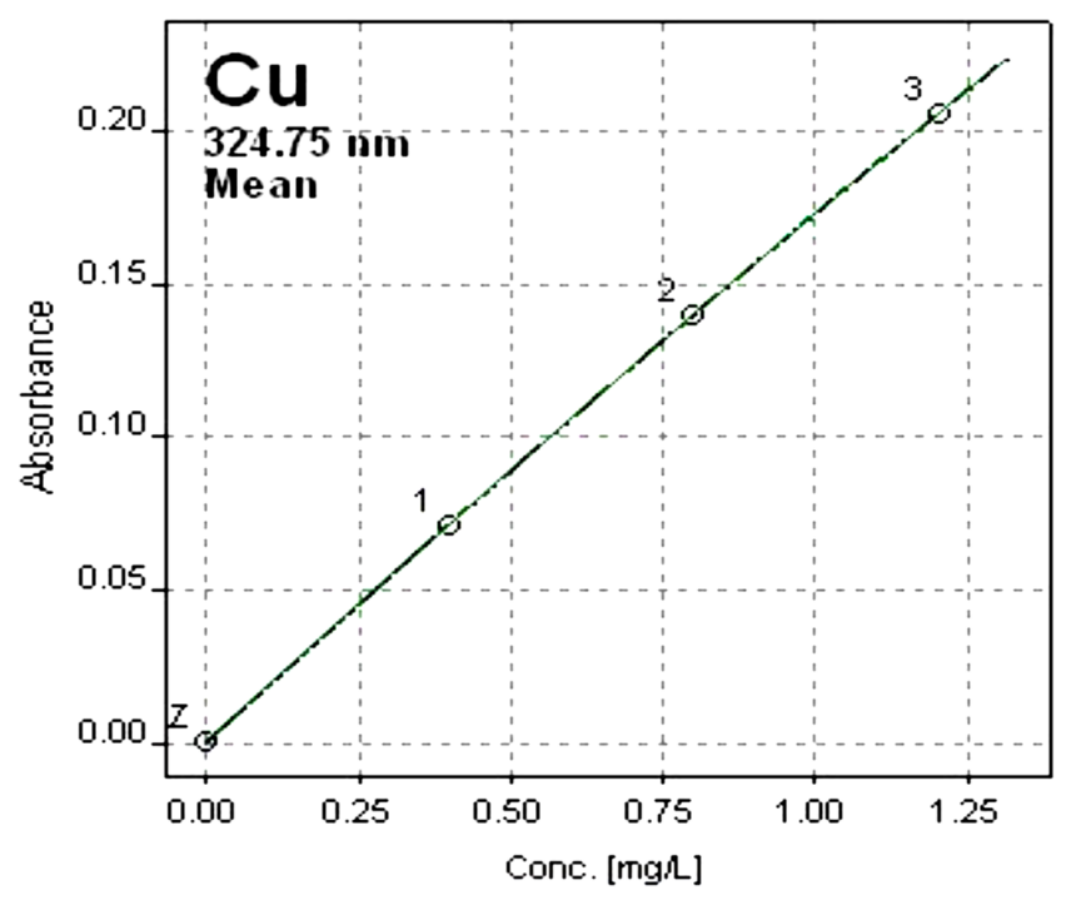

Figure 1. Calibration Curve of Copper.

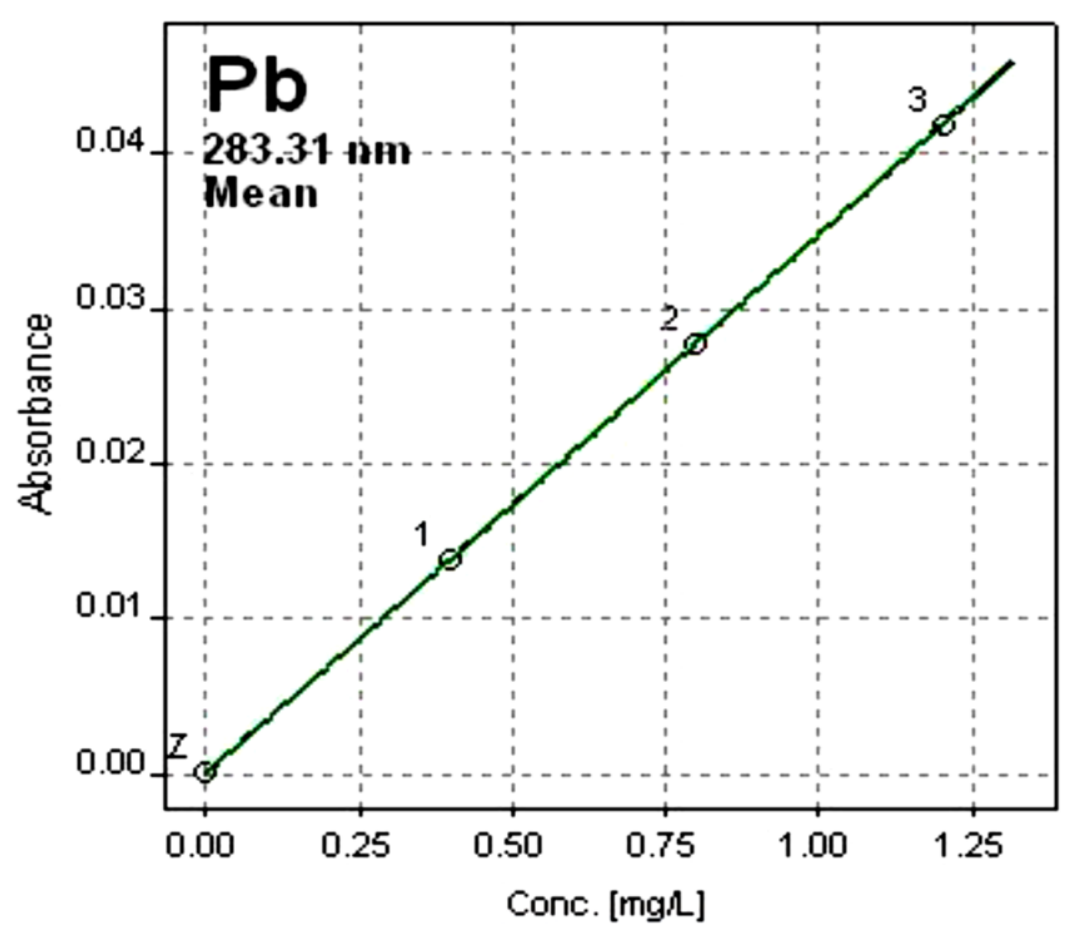

Figure 2. Calibration Curve of Lead. 
Table 1. Concentration of copper and lead in raw milk.

\begin{tabular}{|c|c|c|}
\hline \multirow[b]{2}{*}{ Sample no. } & \multicolumn{2}{|c|}{ Concentration in $\mathrm{mg} / \mathrm{kg}$} \\
\hline & $\begin{array}{c}\text { Copper } \\
(\text { mean } \pm \text { SEM })\end{array}$ & $\begin{array}{c}\text { Lead } \\
(\text { mean } \pm \mathrm{SEM})\end{array}$ \\
\hline M-1 & $0.028 \pm 0.0004$ & $0.015 \pm 0.0005$ \\
\hline M-2 & $0.104 \pm 0.0020$ & $0.008 \pm 0.0002$ \\
\hline M-3 & $0.023 \pm 0.0007$ & $0.016 \pm 0.0008$ \\
\hline M-4 & $0.017 \pm 0.0003$ & 0.000 \\
\hline M-5 & $0.012 \pm 0.0005$ & $0.011 \pm 0.0010$ \\
\hline M-6 & $0.018 \pm 0.0007$ & $0.010 \pm 0.0006$ \\
\hline M-7 & $0.092 \pm 0.0014$ & $0.020 \pm 0.0008$ \\
\hline M-8 & $0.134 \pm 0.0020$ & $0.016 \pm 0.0021$ \\
\hline M-9 & $0.077 \pm 0.0005$ & $0.009 \pm 0.0005$ \\
\hline M-10 & $0.177 \pm 0.0032$ & 0.000 \\
\hline M-11 & $0.112 \pm 0.0015$ & $0.007 \pm 0.0006$ \\
\hline M-12 & $0.271 \pm 0.0022$ & $0.010 \pm 0.0011$ \\
\hline M-13 & $0.188 \pm 0.0032$ & 0.000 \\
\hline M-14 & $0.141 \pm 0.0025$ & $0.004 \pm 0.0005$ \\
\hline M-15 & $0.395 \pm 0.0038$ & $0.006 \pm 0.0009$ \\
\hline M-16 & $0.122 \pm 0.0021$ & $0.014 \pm 0.0012$ \\
\hline M-17 & $0.287 \pm 0.0027$ & $0.005 \pm 0.0003$ \\
\hline M-18 & $0.480 \pm 0.0020$ & $0.011 \pm 0.0010$ \\
\hline M-19 & $0.032 \pm 0.0007$ & $0.008 \pm 0.0007$ \\
\hline M-20 & $0.137 \pm 0.0024$ & $0.013 \pm 0.0008$ \\
\hline M-21 & $0.237 \pm 0.0033$ & $0.018 \pm 0.0011$ \\
\hline M-22 & $0.163 \pm 0.0026$ & $0.009 \pm 0.0006$ \\
\hline M-23 & $0.068 \pm 0.0004$ & $0.016 \pm 0.0008$ \\
\hline M-24 & $0.114 \pm 0.0014$ & $0.012 \pm 0.0007$ \\
\hline M-25 & $0.304 \pm 0.0037$ & $0.015 \pm 0.0010$ \\
\hline
\end{tabular}


The concentration of copper and lead in milk products (yoghurt and ghee) are given in Table 2. The copper concentration was in the interval from $0.08 \mathrm{mg} / \mathrm{kg}$ to $0.25 \mathrm{mg} / \mathrm{kg}$ in most of all yoghurt and ghee samples. The highest level of copper was found $0.244 \mathrm{mg} / \mathrm{kg}$ in yoghurt and $0.204 \mathrm{mg} / \mathrm{kg}$ in ghee. Most of all milk products contains low amount of lead and the value was below the maximum allowed limit. Concentration of lead was in the range from $0.007 \mathrm{mg} / \mathrm{kg}$ to $0.016 \mathrm{mg} / \mathrm{kg}$ in most of all milk products. The maximum concentration of lead was $0.016 \mathrm{mg} / \mathrm{kg}$ in yoghurt and $0.015 \mathrm{mg} / \mathrm{kg}$ in ghee.

Table 2. Concentration of copper and lead in milk products (yoghurt and ghee).

\begin{tabular}{|c|c|c|}
\hline \multirow{2}{*}{ Sample no. } & \multicolumn{2}{|c|}{ Concentration in mg/kg } \\
\cline { 2 - 3 } & $\begin{array}{c}\text { Copper } \\
\text { (mean } \pm \text { SEM) }\end{array}$ & $\begin{array}{c}\text { Lead } \\
\text { (mean } \pm \text { SEM) }\end{array}$ \\
\hline MY-1 & $0.163 \pm 0.0076$ & $0.011 \pm 0.0021$ \\
\hline MY-2 & $0.214 \pm 0.0101$ & $0.007 \pm 0.0006$ \\
\hline MY-3 & $0.244 \pm 0.0237$ & $0.012 \pm 0.0032$ \\
\hline MY-4 & $0.462 \pm 0.0182$ & $0.009 \pm 0.0008$ \\
\hline MY-5 & $0.394 \pm 0.0104$ & $0.014 \pm 0.0052$ \\
\hline MY-6 & $0.165 \pm 0.0082$ & 0.000 \\
\hline MY-7 & $0.601 \pm 0.0326$ & $0.010 \pm 0.0060$ \\
\hline MY-8 & $0.085 \pm 0.0021$ & $0.016 \pm 0.0054$ \\
\hline MG-9 & $0.182 \pm 0.0088$ & $0.008 \pm 0.0007$ \\
\hline MG-10 & $0.741 \pm 0.0382$ & $0.014 \pm 0.0044$ \\
\hline MG-11 & $0.490 \pm 0.0214$ & $0.013 \pm 0.0042$ \\
\hline MG-12 & $0.835 \pm 0.0648$ & $0.010 \pm 0.0035$ \\
\hline MG-13 & $0.745 \pm 0.0537$ & 0.000 \\
\hline MG-14 & $0.534 \pm 0.0342$ & $0.012 \pm 0.0028$ \\
\hline MG-15 & $0.264 \pm 0.0163$ & $0.015 \pm 0.0036$ \\
\hline
\end{tabular}

The Codex alimentarius used to lay down a maximum of $0.1 \mathrm{mg} / \mathrm{kg}$ for copper in butter $^{14}$. The current applicable standard gives no data for copper. According to Codex Alimentarius the permeable value of lead in milk and secondary milk products are 0.02 $\mathrm{mg} / \mathrm{kg}^{15}$. In this study, the copper content of some samples exceed $0.1 \mathrm{mg} / \mathrm{kg}$ where as lead content in all of the samples was found under maximum permeable limit. The maximum concentration of lead in milk sample was found $0.020 \mathrm{mg} / \mathrm{kg}$ which is the safe limit for lead in milk and milk products. 
Enb et. al (2009) reported level of copper in milk from buffalo and cow are 0.212 $\mathrm{mg} / \mathrm{kg}$ and $0.142 \mathrm{mg} / \mathrm{kg}$ respectively. According to Codex Alimentarius this result was found greater than the maximum limit of copper in butter. On the other hand, the lead content was detected in both milk samples in lower values ${ }^{16}$. Ayar et. al (2009) reported the lead concentrations in powder milk were found to exceed the maximum allowed limit for $\mathrm{Pb}$ in milk powder and cheese that was set as $0.2 \mathrm{mg} / \mathrm{kg}^{17}$. Tripathi et. al. (1999) reported that $\mathrm{Cu}$ and $\mathrm{Pb}$ were detected in cow's and buffalo's milk samples at levels ranged between 0.043 $0.195 \mathrm{mg} / 1$ and 1.70-3.35 $\mu \mathrm{g} / 1$ respectively ${ }^{18}$. However, Onianwa et. al. (1999) determined Cu and $\mathrm{Pb}$ at levels ranged from $0.07-0.67$ and $0.03-0.18 \mathrm{mg} / 1$ respectively ${ }^{19}$. Lante et al. (2004) reported that $\mathrm{Cu}(0.0518 \mathrm{mg} / \mathrm{l})$ and $\mathrm{Pb}(5.23 \mu \mathrm{g} / \mathrm{l})$ were detected at various levels ${ }^{20}$.

\section{CONCLUSIONS}

The purpose of this study was to focus concentration of selected metals in raw milk and milk products. The results of this study showed higher concentration of copper in milk products than in raw milk. Lead concentration was observed within maximum limit both in raw milk and milk products. Comparing results of the present study with those of other studies revealed similar levels of metals in milk and milk products investigated in the present study. However, the number of analyzed heavy metals and sample size were limited in our study and further studies are necessary to evaluate the contents of "essential" and "toxic" heavy metals on a greater number of milk samples from various region of Bangladesh and to confirm the absence of possible toxicological risks.

\section{ACKNOWLEDGEMENT}

The authors are greatful to University Grant Commission of Bangladesh for kindly providing financial support to carry out this research work.

\section{References}

[1] L. Jarup, British Medical Journal 68 (2003) 167-182.

[2] M. M. Islam, M. A. Halim, S. Safiullah, S.A. M. Waliul Hoque, M. Saiful Islam, Research Journal of Environmental Sciences 3(3) (2009) 311-315.

[3] M. A. Awal, W. H. G. Hale, B. Stern, Marine Pollution Bulletin 58(12) (2009) 1944-1948.

[4] M. G. M. Alam, E. T. Snow, A. Tanaka, Bangladesh Science of the Total Environment, 308(1-3) (2003) 83-96.

[5] National Food Policy Plan of Action 2008-2015. Food Planning and Monitoring Unit (FPMU), Ministry of Food and Disaster Management, Government of the People's Republic of Bangladesh 2008.

[6] N. R. Bader, Rasayan Journal of Chemistry 4(1) (2011) 49-55.

[7] R. Bock, Handbook of Decomposition Methods in Analytical Chemistry, Willey, New York, translated and revised by I.L. Marr 1979. 
[8] F. Barbosa Jr., C. Palmer, F. J. Krug, P. J. Parsons, Journal of Analytical Atomic Spectrometry 19 (2004) 1000-1005.

[9] J. A. Nobrega, M. C. Santos, R. A. Sousa, S. Cadore, R. M. Barnes, M Tatro, Spectrochimica Acta Part B 61(5) (2006) 465-495.

[10] R. Anderson, Sample Pretreatment and Separation, John Wiley and Sons, New York, 1987.

[11] E. M. Flores, J. S. Barin, M. F. Mesko, G. Knapp, Spectrochimica Acta Part B 62(9) (2007) 1051-1067.

[12] I. Al-Saleh, N. Shinwari, Biological Trace Element Research 83 (2001) 91-96.

[13] J. M. Llobet, G. Falcoa, C. Casas, A. Teixidoa, J. L. Domingo, Journal of Agricultural and Food Chemistry 51 (2003) 838-842.

[14] Codex Standard for Butter; Codex Stan A-1-1971, Rev. 1-1999; $\mathrm{ftp}: / / \mathrm{ftp}$. fao.org/codex/standard/en/CXS_A01e.pdf

[15] Joint FAO/WHO Food Standards Programme, Codex Committee on Contaminants in Foods, Sixth Session, Maastricht, the Netherlands, CF/6 INF/1, 2012.

[16] A. Enb, M. A. Abou-Donia, N. S. Abd-Rabou, A. A. K. Abou-Arab, M. H. El-Senaity, Global Veterinaria 3(3) (2009) 268-275.

[17] A. Ayar, D. Sert, N. Akin, Environmental Monitoring Assessment 152 (2009) 1-12.

[18] R. M. Tripathi, R. Raghunath, V. N. Sastry, T. M. Krishnamoorthy, The Science of the Total Environment 227 (1999) 229-235.

[19] P. C. Onianwa, I. G. Adetola, C. M. A. Iwegbue, M. F. Ojo, O. O. Tella, Food Chemistry 66 (1999) 275-279.

[20] A. Lante, G. Lomolino, M. Cagnin, P. Spettoli, Food Control 17 (2004) 229-233. 